\title{
„NAJCZYSTSZE ZWIERCIADLO CZYSTOŚCI” W KLASZTORZE BENEDYKTYNEK W STANIĄTKACH
}

\section{Streszczenie}

W zbiorach klasztoru Benedyktynek w Staniątkach znajduje się obraz ukazujący założycieli zakonu adorujących Matkę Bożą z Dzieciątkiem i św. Józefem na tle ogrodu $\mathrm{z}$ fontanną i zabudowaniami. Ta $\mathrm{z}$ pozoru rodzajowa i łatwa do określenia tematyka przedstawienia, którą można odnaleźć odnotowaną $\mathrm{w}$ przechowywanych $\mathrm{w}$ konwencie archiwalnych zapisach, jest powielana przez wielu badaczy. Okazuje się jednak, że pod postaciami świętych Benedykta i Scholastyki, namalowanymi w tym konkretnym kontekście, mogą kryć się głębsze treści. Może za tym przemawiać wskazanie wzoru graficznego dokładnie odpowiadającego układem wersji malarskiej. Chodzi o jedną z rycin należącą do cyklu miedziorytów wykonanych przez Raphaela Sadelera Młodszego, na podstawie kompozycji kapucyna Paola Piazzy. Pod postaciami przedstawicieli najważniejszych zakonów (franciszkanów, benedyktynów i dominikanów) towarzyszących wydarzeniom z życia Zbawiciela starał się on zobrazować trzy podstawowe śluby zakonne: ubóstwa, czystości i posłuszeństwa, będące zobowiązaniem do wypełniania rad ewangelicznych. Malowidło przechowywane w klasztorze w Staniątkach odpowiada wizualnie ilustracji cnoty czystości. Brak pozostałych obrazów wzorowanych na serii graficznej nie świadczy, że opisywane przedstawienie nie mogło być nośnikiem wskazanych w artykule treści. Równocześnie nie można mieć też pewności, czy tak było rozumiane jego znaczenie. Porównanie z niewątpliwym wzorem graficznym pozwala jednak nie tylko wskazać źródło formalne kompozycji. Stanowi również punkt wyjścia do wyjaśnienia teologicznych podstaw dzieła funkcjonującego w murach klasztoru.

Słowa kluczowe: Święta Rodzina; św. Benedykt; św. Scholastyka; Staniątki; śluby zakonne; Paolo Piazza; Raphael Sadeler Młodszy

\footnotetext{
* Katarzyna Ponińska - dr histoii sztuki, Instytut Historii Sztuki, Uniwersytet Kardynała Stefana Wyszyńskiego w Warszawie

e-mail:k.poninska@uksw.edu.pl

https://orcid.org/0000-0003-3555-0099
} 
Wśród obrazów, jakie znajdują się w murach klasztoru ss. Benedyktynek w Staniątkach, jest średnich rozmiarów wizerunek (il. 1) patronów zakonu - świętych Benedykta i jego siostry Scholastyki, którzy adorują Matkę Bożą z Dzieciątkiem, datowany ogólnie na XVII/XVIII wiek.

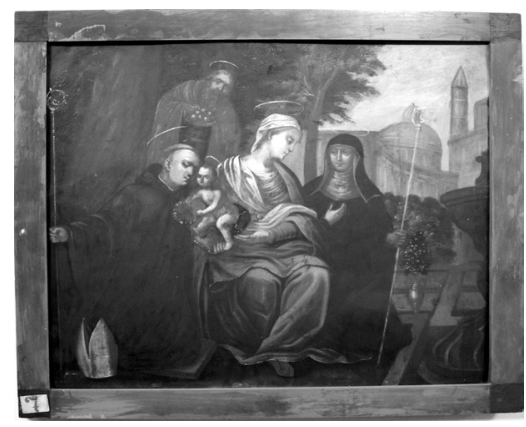

Il. 1. Obraz najczystszej czystości, XVII/XVIII w., przedstawienie malowane olejno na blasze, klasztor Benedyktynek, Staniątki. Fot. Katarzyna Ponińska

Na drugim planie został ukazany św. Józef. Odpowiedni Katalog Zabytków Sztuki $w$ Polsce nie wymienia tego przedstawienia ${ }^{1}$. Najstarsza znaleziona wzmianka na jego temat to zapis w kronice spisywanej najprawdopodobniej przez siostrę Antoninę Scholastykę Kaładulską, która pod datą 1882 r. odnotowała: „obraz na blasze grubej, miedzianej znajdował się w sali rekreacyjnej" ${ }^{2}$. O zmianie jego lokalizacji świadczy wykonany ołówkiem dopisek: „dorm. nowicjackie przy drzwiach składn kościel.”, zamieszczony w pochodzącym z początku XX wieku Spisie obrazów klasztoru Staniateckiego. Na ten okres datowana jest pomalowana na biało blaszka z cyfrą: „7”, umocowana w lewym dolnym rogu ramy obrazu, która odpowiada numerowi opisu w tymże spisie. Zawiera on następujące informacje: „Św. Scholastyka i św. O. Benedykt - podaje owoce Matce Bożej. Obok św. Józef. Obraz silnie malowany na blasze miedzianej. Wysokość obrazu $49 \mathrm{ctm}$. szerokość 58 ctm.”. Czerwony kolor wspomnianej cyfry ma oznaczać zaliczenie malowidła do przedstawień z XVII wieku, ponieważ taki klucz zastosowano w tym inwentarzu, opracowanym pod kierunkiem Juliana Makarewicza, gdzie ponadto zabytki z XVIII stulecia oznaczono kolorem czarnym a z XIX - niebieskim ${ }^{3}$. Zapewne z cytowanej wyżej notatki (ze wspomnianego spisu) zaczerpnęła rozmiary obrazu Halina Blak, opracowując w 1973 r. jego kartę inwentaryzacyjną, błędnie poda-

${ }^{1}$ Katalog Zabytków Sztuki w Polsce, t. 1: Województwo krakowskie, red. J. Szablowski, z. 2: Powiat bocheński, oprac. J.E. Dutkiewicz (miejscowość Staniątki, oprac. Z. Boczkowska), Warszawa 1951, s. 17-21.

${ }^{2}$ Archiwum Opactwa Benedyktynek w Staniątkach (dalej: AOBS), nr inw. 208, [A.S. Kaładulska], Kronika klasztoru staniąteckiego za czasów P(anny) X(ieni) Z(ofii) L(udgardy) Baryszewskiej 1865-1882, t. II, 1865-1882, 1907-1939, s. 304-305.

${ }^{3}$ AOBS, nr inw. 659, Spis obrazów klasztoru Staniąteckiego, s. 7. Rękopis został wymieniony w publikacji: Inwentarz Archiwum Benedyktynek w Staniatkach, oprac. W. Kolak, J. Marecki, S. Radoń, Kraków 2003, s. 175. 
jąc, że został namalowany na płótnie ${ }^{4}$. Jego datacja została tam określona na XVII/ XVIII wiek. Identycznie czas powstania podał Bogusław Krasnowolski w najnowszym opracowaniu na temat zbiorów klasztoru w Staniątkach. Można w nim znaleźć informacje, że malowidło zostało wykonane farbami olejnymi na miedzianej blasze o wymiarach: $50,5 \times 59 \mathrm{~cm}$ (rozmiary z ramą, datowaną na pierwszą połowę XIX wieku, wynoszą: $57 \times 66 \mathrm{~cm}$ ). Wskazana tam aktualna lokalizacja obrazu to: korytarz drugiego piętra w skrzydle południowym ${ }^{5}$. Przedstawienie mogło być również uwzględnione w innych, niż podane wyżej, spisach. Wskazuje na to malowany majuskułą z użyciem czerwonej farby napis: „Nō: 21./ S: SCHOLASTICA ET S: BENEDICTUS" znajdujący się na odwrocie podobrazia (il. 2), który został odnotowany przez Krasnowolskiego. Ponadto w okolicach lewego górnego narożnika ramy, z tyłu jest naklejona kartka z napisaną odręcznie liczbą: „65”, której nie wspomina żadne opracowanie.



Il. 2. Odwrocie przedstawienia: Obraz najczystszej czystości, klasztor Benedyktynek, Staniątki. Fot. Katarzyna Ponińska

Na pierwszym planie przedstawienia ukazano siedzącą Matkę Bożą, która na poduszce podaje Dzieciątko skierowane do klęczącego po Jej prawicy św. Benedykta. Sama zaś zwraca się w stronę klęczącej po przeciwnej stronie św. Scholastyki. Zarówno mniszka, jak i jej brat trzymają w swych dłoniach pastorały oznaczające pełnione przez nich funkcje. Dodatkowo u podstawy pastorału zakonnika znajduje się infuła opacka. Na drugim planie widać starszego, siwiejącego mężczyznę z brodą, niosącego najprawdopodobniej talerz lub tacę z owocami, którego należy zidentyfikować jako św. Józefa. W tle są widoczne drzewa i kwatery ogrodowe. Horyzont zamykają monumentalne budowle z kopułą i wieżą.

Ta z pozoru konwencjonalna scena religijna może kryć w sobie głębsze treści. Jej zawoalowane znaczenie staje się możliwe do odczytania dzięki wskazaniu wzoru, na którym zostało oparte omawiane malowidło. Jest nim rycina (il. 3) wy-

${ }^{4}$ Karta Inwentaryzacyjna Narodowego Instytutu Dziedzictwa (MLP 000000026 829), oprac. H. Blak, 1973.

${ }^{5}$ B. Krasnowolski, Święta Rodzina ze św. Scholastyka i św. Benedyktem, w: Katalog zbiorów artystycznych Opactwa Mniszek Benedyktynek w Staniątkach, t. 2, red. K. Kuczman, J. Skrabski, A. Włodarek, Kraków 2018, II/29, s. 148-149. Za informacje na temat opracowań dotyczących obrazów z klasztoru w Staniątkach dziękuję dr Beacie Frey-Stecowej, która jest współautorką ostatniej publikacji. 
konana przez Raphaela Sadelera II (Młodszego) na podstawie kompozycji stworzonej przez Paola Piazzę. Świadczy o tym adres wydawniczy umieszczony wzdłuż dolnej krawędzi kompozycji: „Raphael Sadeler Iunior scalpsit et excudit/ P. Piazza a C. Franco jnuentor/ Cum priu. S. P. et S. C. M.”6.

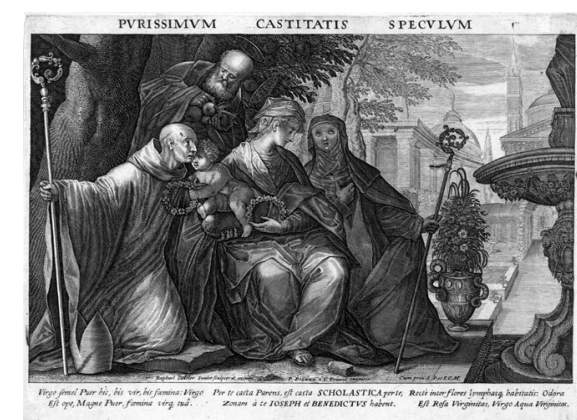

Il. 3. Raphael Sadeler II (Młodszy) według Paola Piazzy, PVRISSIMVM CASTITATIS SPECVLUM, 1594-1632, miedzioryt na papierze, Rijksmuseum, Amsterdam.

Fot. Rijksmuseum, Amsterdam

Miedzioryt zatytułowany w nagłówku: „PVRISSIMVM CASTITATIS SPECVLUM” oznajmia, że jego zadaniem jest zilustrowanie „najczystszej czystości” (dosłownie: „Najczystsze Zwierciadło Czystości”). W tym celu ukazano benedyktyńskich świętych, na co jednoznacznie wskazują ich imiona występujące w inskrypcji, która jest wierszowanym dystychem elegijnym (naprzemiennie heksametr i pentametr daktyliczny). Została ona podzielona na trzy dwuwersowe kolumny i w oryginale brzmi następująco:

Virgo semel Puer hic, bis vir, bis fomina: Virgo

Est ope, Magne Puer, fœmina virq[ue] tuâ.

Per te casta Parens, est casta SCHOLASTICA per te,

Zonam à te IOSEPH et BENEDICTVS habent.

Rectè inter flores lymphasq[ue] habitatis: Odora

Est Rosa Virginitas, Virgo Aqua Virginitas.

Co można następująco przetłumaczyć prozą na polski:

Jedno dziewicze Dziecię, dwóch mężów, dwie niewiasty

Za Twoją sprawą, Wielkie Dziecię, są dziewicą mąż i niewiasta.

${ }^{6}$ Ostatnie słowa mówią, że grafika została wydana z pozwoleniem cenzury kościelnej (,S.P.”„Superiorum Permissu” i przywilejem „S. C. M.”, który to skrót najprawdopodobniej oznacza: „Suae Caesareae Maiestatis” czyli „Jego Cesarskiej Mości” lub „Jego Wysokości Cesarza”). W tym miejscu chciałam serdecznie podziękować p. Marcinowi Beściakowi za tłumaczenie i szczegółowe opracowanie łacińskich inskrypcji.

${ }^{7}$ Komentarz thumacza: W łacinie czym innym jest puritas (czystość w sensie bezpośrednim jako brak brudu: czyste zwierciadło), czym innym castitas (czystość w sensie przenośnym jako cnota wstrzemięźliwości i dziewiczości: zwierciadło czystości). Z braku odpowiedniej alternatywy w thumaczeniu dwukrotnie został użyty ten sam wyraz.

${ }^{8}$ Dosłownie: „Raz Dziecię, dwakroć mąż, dwakroć niewiasta”. Użycie przysłówka liczebnikowego w miejsce liczebnika podyktowane jest wymogami metryki łacińskiej (komentarz thumacza). 
Przez Ciebie czysta jest Rodzicielka. Przez Ciebie czysta Scholastyka.

A Józef i Benedykt od Ciebie otrzymali pasek.

Słusznie przebywacie wśród kwiatów i wód:

Bo dziewictwo jest wonną różą, dziewictwo jest nietkniętym źródłem9.

Wspomniany w czwartym wersie pasek lub pas już w starożytności (u Greków i Rzymian) symbolizował czystość. W Rzymie noszenie tuniki w sposób luźny, bez przewiązania było dozwolone tylko w obrębie domu, poza nim zaś oznaczało zniewieściałe wygodnictwo lub rozwiązłe obyczaje. W średniowieczu istniał zakaz noszenia pasów przez nierządnice. Pasy były również ważnym elementem kultury rycerskiej i szlacheckiej ${ }^{10}$. Biodra były uważane za siedlisko pożądliwości, dlatego krępujący je pasek symbolizował powściągliwość, karność, umartwienie ciała, czystość i dziewictwo ${ }^{11}$. Przepasanie bioder oznaczało skupianie wszystkich sił duchowych i w tym znaczeniu zwracał się Bóg do Hioba $(\mathrm{Hb}$ 38,3), mówiąc: „Przepasz jako mąż biodra twoje”. Cingulum używane przez kapłana w Kościele katolickim do przewiązywania alby było trzecim z kolei nakładanym przez księdza elementem stroju liturgicznego (używanego podczas mszy św.), symbolizującym czystość. Przy jego wiązaniu wymawiał on znamienne słowa łacińskiej modlitwy, która pochodziła z początku wieków średnich i w tłumaczeniu brzmi następująco: „Opasz mię, Panie, paskiem czystości i wygaś w biodrach moich żar pożądliwości, aby królowała we mnie cnota wstrzemięźliwości i czystości"'12. W zakonach benedyktyńskich, podczas obrzędu obłóczyn zakonników, dodaje się słowa nawiązujące do tekstu Ewangelii według św. Jana (J 21,18): „Sprawiedliwość niech będzie pasem twoich bioder. Pamiętaj, że inny cię opasze i poprowadzi, dokąd nie chcesz!’. Natomiast podczas obłóczyn mniszek z tej kon-

${ }^{9}$ Dosłownie: „dziewiczą wodą”, jednak w poezji łacińskiej często używa się słowa woda w znaczeniu źródło, jeśli wymagają tego względy iloczasu (komentarz tłumacza).

${ }^{10}$ Zob. „Pasy” i „Pasowanie rycerzy” w: Z. Gloger, Encyklopedia staropolska ilustrowana, t. 3, wstęp J. Krzyżanowski, Warszawa 1996, s. 323-328. Warto dodać, że pretendent do pasowania na rycerza do „obrzędu tego przygotowywał się przez oczyszczenie moralne (spowiedź) i fizyczne (kąpiel), występował w białej szacie niewinności, a po pasowaniu, damy wkładały na niego zbroję". Tamże, s. 324. Na temat pasów por. J. Kitowicz, Opis obyczajów za panowania Augusta III, wstęp M. Dernałowicz, Warszawa 1985, s. 251-252; M. Michałowska, Leksykon włókiennictwa. Surowce i barwniki, narzędzia i maszyny, techniki i technologie, wyroby i dziedziny, Warszawa 2006, s. 270271.

${ }^{11}$ Można tu wskazać odniesienia do takiego symbolicznego znaczenia zarówno w Piśmie Świętym (por. Łk 12,35: „Niech będą przepasane biodra wasze” czy Ef 6,14), jak i u późniejszych egzegetów. A.J. Nowowiejski, Wykład liturgii Kościoła katolickiego, t. 2, cz. 1: O środkach rozwinięcia kultu, Warszawa 1902, s. 171-180. Por. D. Forstner, Świat symboliki chrześcijańskiej, thum. i oprac. W. Zakrzewska, P. Pachciarek, R. Turzyński, wybór ilustracji i komentarz T. Łozińska, Warszawa 1990, s. 449-451; M. Lurker, Stownik obrazów i symboli biblijnych, tłum. K. Romaniuk, Poznań 1989, s. $168-169$.

${ }^{12}$ E. Andrzejewska, Skarby z dawnej zakrystii. Zabytkowe szaty liturgiczne z Sanktuarium św. Józefa w Kaliszu, Kalisz 2018, s. 13-14. Po soborze watykańskim II noszenie cingulum przez kapłanów nie jest koniecznie wymagane i uzależnia się je od kroju alby. 
gregacji mówi się: „Pan opasuje cię pasem sprawiedliwości i pasem czystości, abyś zasłużyła wejść do komnaty ślubnej Boskiego Oblubieńca!"13.

Grafika pozwala również precyzyjniej określić mniej czytelne elementy malowidła. Delikatnie zaznaczone na obrazie białe wieńce trzymane w dłoniach przez Matkę i Syna są dobrze widoczne na sztychu i najwyraźniej przeznaczone dla klęczącego rodzeństwa. W wersji graficznej bardziej czytelne są także fragment fontanny na pierwszym planie i kwiaty w wazonie, stojące za ksienią. Dostrzegalne są tylko nieznaczne różnice w obu rodzajach przedstawień. Święty Benedykt, w wersji malarskiej, ma spuszczony wzrok i jego głowa nie jest tak bardzo zbliżona do twarzy Jezusa jak na grafice. Również św. Scholastyka, przykładając prawą dłoń do piersi, nie patrzy w górę, ale w stronę Matki Bożej. Ponadto św. Józef na rycinie ma wysokie łysiejące czoło, które mocno eksponuje, opuszczając głowę w dół. Owoce trzyma bezpośrednio w obu dłoniach, bez użycia naczynia. Poza tymi i innymi drobnymi szczegółami stanowiącymi o odmienności obu przedstawień są one tak bardzo podobne, że bez obawy popełnienia błędu można wskazać na tę właśnie grafikę jako wzór dla obrazu w Staniątkach.

Opisywaną rycinę udostępnia, w formie elektronicznej, Rijksmuseum w Amsterdamie $^{14}$ jako dzieło powstałe w latach 1594-1632. W pomnikowym opracowaniu dotyczącym grafiki holenderskiej i flamandzkiej, zapoczątkowanym przez Friedricha Wilhelma Hollsteina, w tomie poświęconym artystycznej rodzinie Sadelerów, zostało odnotowane, że omawiany sztych należy do cyklu złożonego $\mathrm{z}$ trzech rycin obrazujących jeszcze dwie inne cnoty: ubóstwo i posłuszeństwo ${ }^{15}$.

„Najjaśniejsze zwierciadło ubóstwa” zilustrowano sceną, gdzie nowo narodzone Dzieciątko, leżące w grocie na sianie, jest adorowane przez klęczących i pochylających się nad Nim świętych Franciszka i Klarę. Informuje o tym tytułowy nagłówek: „ILLVSTRE PAVPERTATIS SPECVLVM”. Tu, podobnie jak w całej serii, występuje wierszowana łacińska inskrypcja, która brzmi:

Omnia cum superi celârunt munera terram,

Terra suis opibus visa superba fuit.

Omnia cum superi dederunt sua munera terræ,

Terra, velut spectas, cœpit habere NIHIL.

NIL tamen hoc gemmas, NIL auri pondera vincit; Illa solent cœlum vendere, NIL emere.

\footnotetext{
${ }^{13}$ Forstner, Świat symboliki, s. 451. Por. Lurker, Stownik obrazów, s. 169.

${ }^{14}$ Jest to odbitka (nr inw. RP-P-OB-7612) wykonana na papierze o rozmiarach: $18,2 \times 24,5 \mathrm{~cm}$, zakupiona do kolekcji w $1816 \mathrm{r}$. Informacje na temat obiektu można znaleźć na stronie internetowej muzeum: https://www.rijksmuseum.nl/en/search (dostęp: 20.06.2020).

${ }^{15}$ Dzieło Hollsteina, który zmarł w 1957 r., jest kontynuowane przez jego następców. Zob. Aegidius Sadeler to Raphael Sadeler II, compiled Dieuwke de Hoop Scheffer, Ed. K.G. Boon, seria: Dutch and Flemish etchings, engravings and woodcuts ca. 1450-1700, Amsterdam 1980, t. 21 (tekst), s. 276-277, pozycje 43-45 oraz t. 22 (ilustracje), il. 44. Rozmiary ryciny według tego opracowania wynoszą: $18,5 \times 24,3 \mathrm{~cm}$.
} 
W języku polskim inskrypcja ma następującą treść:

Gdy niebiosa zakryły wszystkie swe dary przed ziemią ${ }^{16}$,

Ziemia wydawała się bogata swymi dobrami.

Gdy niebiosa wszystkie swe dary dały ziemi,

Ziemia - jak widzisz - zaczęła mieć NIC ${ }^{17}$.

Jednak to NIC cenniejsze jest od pereł i złota,

Bo one sprzedają niebo ${ }^{18}$, a NIC je dla nas kupuje.

W tym wypadku święci z zakonu żebraczego nie zostali wymienieni w inskrypcji, w związku z tym we wspomnianym wcześniej opracowaniu Hollsteina zakonnica została określona jako Klara, ale ze znakiem zapytania. Jej identyfikacja jednak nie powinna budzić wątpliwości, gdyż była duchową córką św. Franciszka z Asyżu i - przez analogię do siostry św. Benedykta - to ona powinna mu towarzyszyć jako przedstawicielka żeńskiej linii zgromadzenia. Na pierwszym planie ponadto ukazano stojącą na kamiennej podstawie monstrancję, która należy do atrybutów tej właśnie świętej. Warto dodać, że św. Klara miała wizję otoczonego światłem Dzieciątka w żłobie w Boże Narodzenie, a św. Franciszek jako pierwszy urządził w kościele w Greccio szopkę odtwarzającą stajenkę w Betle$\mathrm{jem}^{19}$. Na drugim planie widać Matkę Bożą ze skrzyżowanymi na piersiach rękoma oraz łby woła i osła $z$ boku. Jeszcze dalej, po przeciwnej stronie, u wejścia do groty przysiadł św. Józef z zapaloną latarnią stojącą przy jego łokciu. W tle rozciąga się nocny, górski pejzaż z domami i księżycem na niebie.

Egzemplarz sztychu przechowuje w swoich zbiorach m.in. londyńskie British Museum, gdzie czas jego powstania został określony na lata 1600-162020. Inskrypcja poza tym, że mówi o marności bogactw ziemskich w porównaniu z Wcie-

${ }^{16}$ Komentarz tłumacza: „Wszystkie dary niebios” to Wcielone Słowo Boże, Jezus Chrystus, zakryty przed ziemią (czyli światem) w betlejemskiej stajence.

${ }^{17}$ Owo „NIC” pisane wielkimi literami to Sam Jezus Chrystus ogołocony jako Dziecię w żłóbku (komentarz thumacza).

${ }^{18}$ To znaczy: ludzie oddają niebo (zbawienie duszy) w zamian za dobra materialne (komentarz thumacza).

${ }^{19}$ Por. G. van 's-Hertogenbosch, Franz (Franziskus) von Assisi, w: Lexikon der christlichen Ikonographie, Begr. E. Kirschbaum, Hrsg.. W. Braunfels, Ikonographie der heiligen, t. 6, RomFreiburg-Basel-Wien 1974, Wien 1974, szp. 264, 291-292. E. Weis, F. Tschochner, Klara (Chiara) von Assisi, w: Lexikon der christlichen Ikonographie, Begr. E. Kirschbaum, Hrsg. W. Braunfels, Ikonographie der heiligen, t. 7, Rom-Freiburg-Basel-Wien 1974, szp. 314-318. H. Fros, F. Sowa, Księga imion i świętych, t. 2, Kraków 1997, szp. 360-361. V. Schauber, H.M. Schindler, Ilustrowany leksykon świętych, tłum. P. Tkaczyk, R. Zajączkowski, Kielce 2002, s. 377. J. Marecki, L. Rotter, Jak czytać wizerunki świętych. Leksykon atrybutów i symboli hagiograficznych, Kraków 2009, s. 372. I. Chisesi, Co to za święty? Sztuka czytania obrazów. Słownik ikonografii, thum. K. Kozak, Kielce 2018, s. 317-318.

${ }^{20}$ Jest to odbitka ( $\mathrm{nr}$ inw. 1937,0915.377) na papierze o wymiarach: $18,5 \times 24,1 \mathrm{~cm}$, zakupiona do zbiorów w 1937 r. Na stronie internetowej muzeum, zapewne za opracowaniem Aegidius Sade$l e r$, t. 21, s. 276, pozycja 43, przy imieniu św. Klary postawiono znak zapytania. Według tego opracowania rycina ma wielkość: 18,4×24,1 cm. Por. British Museum, Collection online, https://research.britishmuseum.org/research/collection_online/search.aspx (dostęp: 20.06.2020). 
lonym Bogiem określonym tu paradoksalnie jako „NIC” w oczach świata i poza wskazaniem na tych samych co wcześniej twórców zawiera dodatkowo dedykację dla F. Gasperiego z Bergamo - komisarza generalnego tyrolskiej prowincji kapucynów ${ }^{21}$.

$\mathrm{Na}$ trzeciej rycinie z omawianego cyklu (il. 4), pod postacią Chrystusa konającego na Górze Oliwnej, ukazano „najdoskonalsze posłuszeństwo”, na co wskazuje tytuł w nagłówku: „PERFECTISSIMVM OBEDIENTIÆ SPECVLVM”. Opadłego z sił Zbawiciela, który został posłuszny woli Swojego Ojca aż do Ofiary złożonej na Krzyżu, otaczają trzy postacie.

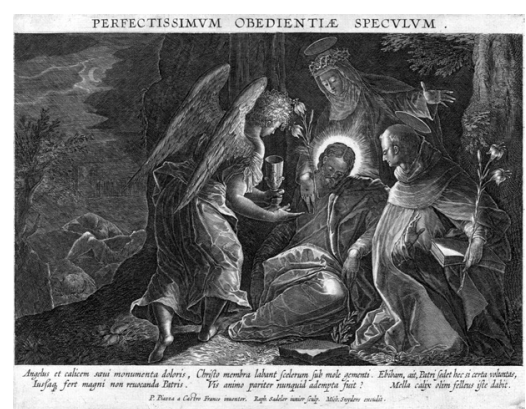

Il. 4. Raphael Sadeler II (Młodszy) według Paola Piazzy, PERFECTISSIMVM OBEDIENTIÆ SPE-

CVLVM, 1596-1632, miedzioryt na papierze, Rijksmuseum, Amsterdam.

Fot. Rijksmuseum, Amsterdam

Z kielichem w dłoni pochyla się nad Nim anioł. Po Jego lewicy widać zakonnika, który we wszystkich opracowaniach jest określany jako św. Dominik, co do mniszki zaś stojącej z lilią w prawej dłoni za Jezusem można się spotkać z dwoma identyfikacjami. W kontynuacji opracowania Hollsteina została ona ze znakiem zapytania określona jako św. Weronika ${ }^{22}$, chociaż jej atrybutem jest chusta z wizerunkiem Zbawiciela, którą otarła Jego oblicze, gdy dźwigał krzyż na Golgotę ${ }^{23}$. Autorom publikacji na pewno nie chodziło o św. Weronikę Giuliani, choć jej atrybutami są również: stygmaty, korona cierniowa i lilie widoczne u świętej z grafiki. Wyklucza ją wszakże przynależność do zakonu kapucynów i rok urodzenia:

${ }^{21}$ Została ona napisana w dwóch wierszach: „R. P. F. Gasperi Bergomensi Commissario Generali Prouinciæ Tirolis FF. Capuccinorum Ordinis S. Francisci, Raph. Sadeler Iunior M. D D./ P. Piazza a Castro Franco Inuentor”. Co oznacza: „Najczcigodniejszemu Ojcu F. Gasperi z Bergamo Komisarzowi Generalnemu Prowincji Tyrolskiej Kapucynów zakonu św. Franciszka Raphael Sadeler Młodszy (M. ku pamięci) (D. D. daje, poświęca, dedykuje); Wymyślił Paolo Piazza z Castel Franco".

${ }^{22}$ Por. Aegidius Sadeler, t. 21, s. 277, pozycja 45, gdzie podano wymiary sztychu: 18,3×23,7 cm.

${ }^{23}$ Por. J.H. Emminghaus, Veronika, w: Lexikon der christlichen Ikonographie, Begr. E. Kirschbaum, Hrsg. W. Braunfels, Ikonographie der heiligen, t. 8, Rom-Freiburg-Basel-Wien 1976, szp. 543-544. Fros, Sowa, Księga imion, t. 6, Kraków 2007, szp. 83-85. Schauber, Schindler, Ilustrowany leksykon, s. 747-749. Marecki, Rotter, Jak czytać wizerunki, s. 604. Chisesi, Co to za święty?, s. 515517. 
$1660^{24}$.Zapewnezawspomnianymopracowaniemnastronie British Museumw Londynie, które posiada odbitkę tej ryciny, pojawia się ze znakiem zapytania taka sama identyfikacja ${ }^{25}$. Przez analogię do dwóch poprzednich przedstawień powinna tu zostać ukazana przedstawicielka zakonu dominikańskiego. Jest nią bez wątpienia św. Katarzyna Sieneńska, określona tak w opisie dwóch egzemplarzy tej grafiki, znajdujących się w zbiorach Rijksmuseum w Amsterdamie ${ }^{26}$. Wskazują na to korona cierniowa na jej głowie i stygmaty na dłoniach, których to łask doznała podczas licznych objawieńn ${ }^{27}$.

Łacińska inskrypcja, tak jak na poprzednio omówionych grafikach, została zestawiona w trzech kolumnach pod przedstawieniem:

Angelus et calicem sœui monumenta doloris,

Iussaq[ue] fert magni non reuocanda Patris.

Christo membra labant scelerum sub mole gementi.

Vis animo partier nunquid adempta fuit?

Ebibam, ait, Patri sedet hec si certa voluntas, Mella calix olim felleus iste dabit."

Co można przełożyć na polski następująco:

Anioł niesie kielich, pamiątkę srogiej Męki

Wraz z nieodwołalnym postanowieniem Wielkiego Ojca.

Członki jęczącego Chrystusa upadają pod ciężarem występków.

Czyż $\dot{z}^{28}$ i siła ducha na równi odjęta Mu została?

Wypiję - powiada - jeśli taka niewzruszona wola Ojca,

Kiedyś ten kielich goryczy płynąć będzie miodem.

${ }^{24}$ Zob. G. van 's-Hertogenbosch, O. Schmucki, Veronika (Orsola) Giuliani, w: Lexikon der christlichen Ikonographie, t. 8, szp. 545-546. Fros, Sowa, Ksiegga imion, t. 6, szp. 85-86. Schauber, Schindler, Ilustrowany leksykon, s. 749. Marecki, Rotter, Jak czytać wizerunki, s. 604-605. Chisesi, Co to za święty?, s. 517.

${ }^{25}$ Miedzioryt (nr inw. 1937,0915.378) na papierze o wymiarach: $18,2 \times 23,7 \mathrm{~cm}$, zakupiony do zbiorów w 1937 r. Por. British Museum, Collection onlinehttps://research.britishmuseum.org/research/collection_online/search.aspx (dostęp: 20.06.2020).

${ }^{26}$ Jedna odbitka (nr inw. RP-P-OB-7613) ma wymiary: 18,5×23,7 cm, druga zaś (nr inw. RP-P -OB-7611) ma obcięte marginesy, przez co przedstawienie zostało pozbawione otaczających ją napisów. Jej rozmiary to: $15,3 \times 23,4 \mathrm{~cm}$. Obie zostały zakupione do kolekcji w $1816 \mathrm{r}$. Zob. Rijksmusseum, https://www.rijksmuseum.nl/en/search (dostęp: 20.06.2020).

${ }^{27}$ Zob. W. Pleister, Katharina (Caterina) von Siena, w: Lexikon der christlichen Ikonographie, t. 7, szp. 301. Fros, Sowa, Księga imion, t. 3, Kraków 1998, szp. 461-463. Schauber, Schindler, Ilustrowany leksykon, s. 371-373. Marecki, Rotter, Jak czytać wizerunki, s. 366-369. Chisesi, Co to za święty?, s. 314-315.

${ }^{28}$ Komentarz tłumacza: Numquid (,czyż?”) - partykuła pytajna używana tam, gdzie autor pytania wie, że odpowiedź jest przecząca. Równie dobrze można byłoby więc przetłumaczyć: „A przecież siła ducha nie została Mu na równi odjęta". 
Święty Dominik, tak jak słynna tercjarka z jego zakonu, trzyma w lewej ręce lilię równocześnie $\mathrm{z}$ otwartą księgą ${ }^{29}$. Na dalszym planie widać trzech uczniów Chrystusa, którzy nie będąc w stanie czuwać całej nocy, zasnęli pod otwartym, pochmurnym niebem, na którym widać zarys sierpa księżyca. Trudności w określeniu świętych nie ułatwia inskrypcja, ponieważ nie zostali oni w niej wymienieni, w przeciwieństwie do wspomnianych wcześniej twórców. Tym razem sztych nie posiada dedykacji, choć znalazła się na nim informacja o wydawcy, którym był Michael Snyders ${ }^{30}$. Można tu zauważyć rozbieżności w datacji grafik ustalonych przez przechowujące je instytucje. Rijksmusem wskazuje lata zbliżone do podanych poprzednio, czyli 1596-1632, British Museum zaś niezmiennie określa czas jej powstania na okres między rokiem 1600 a 1620.

Jak zostało wcześniej wspomniane, twórcą cyklu był flamandzki rytownik Rafael Sadeler II (Młodszy). Według informacji znajdujących się w słownikach artystów urodził się on w Antwerpii 20 grudnia 1584 r. Zapewne z tego względu Rijksmuseum datuje sztychy od 1594 r., w którym Rafael miał 10 lat. Nie powinno to dziwić, ponieważ wywodził się on z artystycznej rodziny, w której trzy pokolenia zajmowały się produkcją graficzną. Jego ojciec - Rafael Sadeler I (Starszy) był rytownikiem i równocześnie uczył Rafaela zawodu, który uprawiali również jego bracia: Jan Sadeler II oraz Filip. W latach 1601-1604 Rafael przebywał w Wenecji. W 1610 r. został przyjęty do Gildii św. Łukasza w Antwerpii. Na tę decyzję bez wątpienia miał wpływu fakt, że był on synem mistrza. W latach 1604-1632 mieszkał w Monachium, gdzie współpracował z ojcem, pod koniec życia zaś działał twórczo z braćmi. Nie ma pewności co do daty i miejsca śmierci artysty. Można się spotkać z dwoma wersjami. Według jednej z nich zmarł być może po 1627 r. w Pradze albo w 1632 w Monachium ${ }^{31}$.

Omawiany cykl graficzny miał powstać na podstawie rysunków Paola Piazzy. Wspomniany pomysłodawca oryginalnych kompozycji był włoskim malarzem i ry-

${ }^{29}$ Nie są to najbardziej charakterystyczne atrybuty tego świętego (jak np. pies z płonącą pochodnią), ale należą do jego repertuaru i mają różne odniesienia do wydarzeń z jego życia. Por. I. Frank, Dominikus von Caleruega (Domingo de Guzmán), w: Lexikon der christlichen Ikonographie, t. 6, szp. 74. Schauber, Schindler, Ilustrowany leksykon, s. 129-130. Marecki, Rotter, Jak czytać wizerunki, s. 155-158. Chisesi, Co to za święty?, s. 149-151.

${ }^{30}$ Została umieszczona poniżej inskrypcji, w jednym wierszu: „P. Piazza a Castro Franco inuentor. Raph. Sadeler iunior sculp. Mich. Snyders excudit."

${ }^{31}$ Ch. van Mulders, Sadeler, w: The Dictionary of Art, t. 27, Ed. J. Turner, London 1996, s. 501505. Allgemeines Lexikon der bildenden Künstler von der Antike bis zur Gegenwart, t. 29, Hrsg. U. Thieme, F. Becker, Leipzig 1935, s. 299-302. G.K. Nagler, Neues allgemeines Künstler-Lexikon oder Nachrichten von dem Leben und den Werken der Maler, Bildhauer, Baumeister, Kupferstecher, Lithographen, Formschneider, Zeichner, Medailleure, Elfenbeinarbeiter, etc., Leipzig 1924, t. 15, s. 548-558; t. 16, s. 1-23. A. von Wurzbach, Niederländisches Künstler-Lexikon, auf Grund archivalischer Forschungen bearbeitet, t. 2, Wien-Leipzig 1910, s. 543-544 podaje ogólnie, że Rafael Sadeler II (Młodszy) urodził się ok. 1590 r., ale nie ma wątpliwości przy określeniu zakonnicy towarzyszącej św. Franciszkowi na omawianej rycinie ukazującej ubóstwo, uznając ją za Klarę (nr 6). E. Bénézit, Dictionnaire critique et documentaire des peintres, sculpteurs, dessinateurs et graveurs de tous les temps et de tous les pays par un groupe d'écrivains spécialistes français et étrangers, t. 9, Paris 1976, s. 220. 
townikiem należącym do starszego pokolenia od Rafaela Sadelera II (Młodszego). Miał się urodzić ok. 1560 r. w Castelfranco. Około 1597 wstąpił do kapucynów, gdzie przyjął imię zakonne Fra Cosimo. W 1606 był na dworze Rudolfa II, w latach 1614-1616 w Rzymie, w 1617 w Weronie, a w 1619 w Wenecji, gdzie zmarł w $1620 \mathrm{r}^{32}$ Wspominany jako wydawca, na rycinie ukazującej „Posłuszeństwo", Michael Snyders był flamandzkim grafikiem, wydawcą i antykwariuszem. Urodził się ok. 1588 r. a w 1611 został członkiem gildii. Pracował w Antwerpii do ok. 1630 r., który jest uznawany za datę jego śmierci33 ${ }^{33}$.

Grafiki należą do cyklu ukazującego trzy sceny z życia Jezusa, których świadkami są przedstawiciele różnych rodzin zakonnych. Wyobrażenia te posłużyły do wyłożenia nauki o doskonałości cnót wyeksponowanych w poszczególnych epizodach oraz u konkretnych świętych mnichów i mniszek. Zilustrowane cnoty są równocześnie trzema podstawowymi ślubami zakonnymi, które zobowiązywały do przestrzegania rad ewangelicznych: czystości, ubóstwa i posłuszeństwa. W zakonie benedyktyńskim obowiązuje również (stabilitas) stałość miejsca (związanie z konkretną wspólnotą), (conservatio morum) przyjęcie monastycznego sposobu życia i (oboedientia) posłuszeństwo zgodne z regułą ${ }^{34}$.

Według Summy teologicznej św. Tomasza rady ewangeliczne, które dał Zbawiciel, przychodząc na świat, miały na celu naprawić ład zniszczony przez grzech pierworodny i przywrócić pierwotną harmonię ${ }^{35}$. Chrystus jest wzorem zachowania tych rad. Jego ubóstwo wyrażało się oderwaniem od dóbr ziemskich, zaszczytów i spraw tego świata, w słowach Ewangelii św. Łukasza (9,58): „nie ma gdzie skłonić głowy”. Był również na tym świecie przykładem czystości i oderwania od wszelkiej własnej woli. Swoim przykładem zachęca do przestrzegania ich w zakonach. Jak pisze Akwinata:

Stan zakonny można pojmować trojako: po pierwsze, jako szkołę dążenia do doskonałej miłości; po drugie, jako spokój duszy i wolność od zewnętrznych trosk, stosownie do słów: «Chcę, abyście byli wolni od trosk»; po trzecie, jako całopalną ofiarę, w której zakonnik całkowicie ofiaruje Bogu siebie i wszystko, co do niego należy. W każdym z tych trzech stan zakonny ukazuje się w całej pełni przez trzy śluby: [...] Ta szkoła i ćwiczenie się w doskonałości wymaga od zakonnika usunięcia z siebie tego, co może przeszkadzać w całkowitym skierowaniu serca ku Bogu, na czym właśnie polega doskonała miłość. Chodzi o trzy przeszkody: pierwszą jest żądza dóbr zewnętrznych - i tę usuwa

${ }^{32}$ W. Arslan, Piazza, Paolo, w: Allgemeines Lexikon, t. 26, Leipzig 1932, s. 567-568 podaje ze znakiem zapytania, że urodził się ok. 1557 r., a zmarł w 1621 r. w Wenecji. Nagler, Neues allgemeines Künstler-Lexikon, t. 12, s. 406-407 informuje, że zmarł w 1621 r. w wieku 64 lat. Bénézit, Dictionnaire critique, t. 8, s. 292 podaje, że urodził się w 1537 lub 1557 r., a zmarł w Wenecji w 1621. Por. informacje ze strony British Museum: https://www.britishmuseum.org/collection/term/ BIOG41916 (dostęp: 20.06.2020).

${ }^{33}$ Wurzbach, Niederländisches Künstler-Lexikon, t. 2, s. 635. Bénézit, Dictionnaire critique, t. 9, s. 674 .

${ }^{34}$ B. Łoziński, Leksykon zakonów w Polsce, Warszawa 1998, s. 30-31, 145-146. M. Borkowska, Życie codzienne polskich klasztorów żeńskich w XVII-XVIII wieku, Warszawa 1996, s. 44-47.

${ }^{35}$ Św. Tomasz, Suma teologiczna, I-a II-ae, q. 108, a. 4, i II-a II-ae, q. 186, a. 3, 4, 5, 7, http:// katedra.uksw.edu.pl/suma/suma_indeks.htm (dostęp: 20.06.2020). 
ślub ubóstwa; drugą jest żądza rozkoszy zmysłowych, wśród których wybijają się rozkosze seksualne - i tę usuwa ślub powściągliwości; trzecią jest niezrównoważenie woli - i tę usuwa ślub posłuszeństwa.

Na podstawie zebranych i przytoczonych informacji trudno zawęzić datację omawianego malowidła. Nawet czas powstania wzorcowej ryciny ma dosyć szerokie ramy, przekraczające trzy dekady, bo sięgające od 1596 po 1632 r. Pierwsza znana wzmianka na temat istnienia wersji malarskiej tej kompozycji w klasztorze Benedyktynek w Staniątkach, pochodzi dopiero z 1882 r., jednak jej cechy stylistyczne wskazują, że powstała znacznie wcześniej. Jej twórca na pewno nie należał do wybitnych artystów, ale widać, że potrafił poprawnie wywiązać się z zadania odtworzenia $\mathrm{w}$ technice olejnej wzoru graficznego, którego też ściśle nie naśladował, ale też nie wykazał się większą inwencją. W związku z tym ostrożne datowanie na dwa stulecia, czyli XVII lub XVIII wiek, wydaje się na tym etapie badań rozsądnym rozwiązaniem.

W zbiorach klasztoru w Staniątkach jest tylko jeden obraz nawiązujący do graficznej kompozycji ukazującej w omawianym cyklu cnotę czystości. Trudno dziś stwierdzić, czy w momencie powstania malowidła stworzono je jako odosobnioną pracę, czy może towarzyszyły mu dwa pozostałe przedstawienia? Może chodziło tylko o ukazanie pojedynczej sceny, na której występują założyciele miejscowej wspólnoty zakonnej? Na to pytanie raczej nie da się uzyskać dziś odpowiedzi, ale dzięki znajomości wzoru można odczytać głębsze treści, jakie ono zawiera i które mogły się kryć w intencji zamawiających zachowane do dziś przedstawienie.

Przeprowadzona analiza obrazu prowadzi do wniosku, że nie jest to wizerunek Świętej Rodziny. Marginalizacja postaci św. Józefa, do którego święci Benedykt i Scholastyka obróceni są niemalże tyłem, dobitnie to potwierdza. Z pewnością dzieło nie jest wyrazem kultu Świętej Rodziny ani św. Józefa. Główną rolę pełni adorowana Matka Boża z Dzieciątkiem. Te fakty trzeba stwierdzić z całą stanowczością wobec nadużywania określenia „Święta Rodzina” w stosunku do dzieł, których tematyka jest odmienna.

\section{REFERENCES / BIBLIOGRAFIA}

\section{Źródla archiwalne}

Archiwum Opactwa Benedyktynek w Staniątkach (AOBS)

nr inw. 208, [A.S. Kaładulska], Kronika klasztoru staniąteckiego za czasów P(anny) X(ie-

ni) Z(ofii) L(udgardy) Baryszewskiej 1865-1882, t. II, s. 304-305.

nr inw. 659, Spis obrazów klasztoru Staniąteckiego, s. 7.

Narodowy Instytut Dziedzictwa (NID)

Karta Inwentaryzacyjna Narodowego Instytutu Dziedzictwa, (MLP 000000026 829), oprac. H. Blak w roku 1973. 


\section{Opracowania}

Aegidius Sadeler to Raphael Sadeler II, compiled Dieuwke de Hoop Scheffer, Ed. K.G. Boon, seria: Dutch and Flemish etchings, engravings and woodcuts ca. 1450-1700, t. 21, 22, Amsterdam 1980.

Allgemeines Lexikon der bildenden Künstler von der Antike bis zur Gegenwart, t. 29, Hrsg. U. Thieme, F. Becker, Leipzig 1935.

Arslan Wart, Piazza, Paolo, w: Allgemeines Lexikon der bildenden Künstler von der Antike bis zur Gegenwart, t. 26, Leipzig 1932, s. 567-568

Bénézit Emmanuel, Dictionnaire critique et documentaire des peintres, sculpteurs, dessinateurs et graveurs de tous les temps et de tous les pays par un groupe d'écrivains spécialistes français et étrangers, t. 8, 9, Paris 1976.

Chisesi Ino, Co to za święty? Sztuka czytania obrazów. Słownik ikonografii, tłum. K. Kozak, Kielce 2018, Kielce 2018.

Fros Henryk, Sowa Franciszek, Księga imion i świętych, t. 2, Kraków 1997.

Fros Henryk, Sowa Franciszek, Księga imion i świętych, t. 3, Kraków 1998.

Fros Henryk, Sowa Franciszek, Księga imion i świętych, t. 6, Kraków 2007.

Inwentarz Archiwum Benedyktynek w Staniatkach, oprac. W. Kolak, J. Marecki, S. Radoń, Kraków 2003.

Katalog Zabytków Sztuki w Polsce, t. 1: Województwo krakowskie, red. J. Szablowski, z. 2: Powiat bocheński, oprac. J. E. Dutkiewicz (miejscowość Staniątki, oprac. Z. Boczkowska), Warszawa 1951.

Krasnowolski Bogusław, Święta Rodzina ze św. Scholastyka i św. Benedyktem, w: Katalog zbiorów artystycznych Opactwa Mniszek Benedyktynek w Staniątkach, red. K. Kuczman, J. Skrabski, A. Włodarek, Kraków 2018, t. 2, II/29, s. 148-149.

Marecki Józef, Rotter Lucyna, Jak czytać wizerunki świętych. Leksykon atrybutów i symboli hagiograficznych, Kraków 2009.

Mulders Christine van, Sadeler, w: The Dictionary of Art, t. 27, Ed. J. Turner, London 1996, s. 501-505.

Nagler Georg Kaspar, Neues allgemeines Künstler-Lexikon oder Nachrichten von dem Leben und den Werken der Maler, Bildhauer, Baumeister, Kupferstecher, Lithographen, Formschneider, Zeichner, Medailleure, Elfenbeinarbeiter, etc., t. 12, 15, 16, Leipzig 1924.

Schauber Vera, Schindler Hans Michael, Ilustrowany leksykon świętych, thum. P. Tkaczyk, R. Zajączkowski, Kielce 2002.

Tomasz z Akwinu św., Suma teologiczna, I-a II-ae, q. 108, a. 4, i II-a II-ae, q. 186, a. 3, 4, 5, 7, http://katedra.uksw.edu.pl/suma/suma_indeks.htm (dostęp: 20.06.2020)

Wurzbach Alfred von, Niederländisches Künstler-Lexikon, auf Grund archivalischer Forschungen bearbeitet, t. 2, Wien-Leipzig 1910.

\section{Netografia}

British Museum, Collection online, https://research.britishmuseum.org/research/collection_online/search.aspx (dostęp: 20.06.2020)

British Museum, Paolo Piazza, https://www.britishmuseum.org/collection/term/ BIOG41916 (dostęp: 20.06.2020)

Rijksmuseum, https://www.rijksmuseum.nl/en/search (dostęp: 20.06.2020) 


\title{
"THE PUREST MIRROR OF PURITY" ("NAJCZYSTSZE ZWIERCIADLO CZYSTOŚCI") IN THE BENEDICTINE MONASTERY IN STANIĄTKI
}

\begin{abstract}
In the collection of the Benedictine monastery in Staniątki there is a painting showing the founders of the order adoring the Mother of God with the Child and St. Joseph against the background of a garden with a fountain and buildings. This, seemingly generic and easy to define subject of the portrayal, which can be found recorded in the archival records kept in the convent, has been duplicated by many researchers. It turns out, however, that the figures of Saints Benedict and St. Scholastica, painted in this specific context, may hide deeper content. This may be indicated by the pointing to a graphic pattern that exactly corresponds to the arrangement of the painted version. It is about one of the engravings belonging to the series of copperplate engravings made by Raphael Sadeler the Younger, based on the compositions of Capuchin Paolo Piazza. Under the figures of representatives of the most important orders (Franciscans, Benedictines and Dominicans) accompanying the events of the Savior's life, he tried to illustrate three basic religious vows: poverty, chastity and obedience, which are an obligation to fulfil the evangelical counsels. The painting kept in the monastery in Staniątki corresponds visually to the illustration of the virtue of chastity. The lack of other paintings modelled on the graphic series does not mean that the described representation could not be the carrier of the content indicated in the article. At the same time, it is also impossible to be certain that its meaning was understood in this way. A comparison with the implicit graphic pattern allows not only to indicate the formal source of the composition. It is also a starting point for explaining the theological foundations of the work functioning within the walls of the monastery.
\end{abstract}

Keywords: Holy Family; St. Benedict; St. Scholastica; Staniątki; Benedictine nuns; religious vows; Paolo Piazza; Raphael Sadeler the Younger 